\title{
Preliminary Evaluation of 21 Certified Virus-free Citrus Clones ${ }^{1}$
}

\author{
Nelson Semidey and Oscar D. Ramírez ${ }^{2}$
}

\begin{abstract}
Twenty-one clonal varieties of citrus were evaluated at the Gurabo Substation fruit yield and characters. Average fruit production during the 3-year study of Pineapple and Temple clones and the majority of the Valencia clones was higher than the ones reported from commercial orchards in Puerto Rico. The clones of Pineapple, Temple and Orlando Tangelo have the most seedy fruits with 18,13 and 13 seeds per fruit, respectively. For most of the clonal varieties, seed content was lower and acceptable. Lue Gin Gong and most of the Valencia clones produced the highest percentages of juice per fruit.
\end{abstract}

\section{INTRODUCTION}

In Puerto Rico, citrus fruits are second among the fruits grown in the Island. Our search for new citrus cultivars, higher in yields, resistant to pests and diseases and of superior fruit characteristics is a continuous task. Introduction, propagation and evaluation of citrus cultivars are important in obtaining new or improved varieties.

This paper presents the results obtained from a preliminary evaluation of 21 citrus clones planted at the Gurabo Substation.

\section{MATERIALS AND METHODS}

Certified virus-free (tristeza, exocortis, psiloporosis) citrus budwood was introduced from Florida in 1962 and 1963. This selected material was grafted on sour orange (Citrus aurantium L.) and rough lemonCitrus limon (L.) Burm.f. - rootstocks and planted at the Gurabo agricultural experiment substation from 1962 to 1965 . The planting distance between trees was $7.6 \times 7.6 \mathrm{~m}$. The soil at the experimental area is Mabí, Vertic Entropepts, fine, motmorillonitic, isohypertemic. The average annual rainfall is around $1650 \mathrm{~mm}$, and maximum and minimum temperatures are around $30^{\circ} \mathrm{C}$ and $18^{\circ} \mathrm{C}$, respectively.

The trees were maintained properly as a farm orchard until 1976. From there on they were managed following recommendations of the Puerto Rico Agricultural Experiment Station. ${ }^{3}$ From 1976 through 1980, when

${ }^{1}$ Manuscript submitted to Editorial Board August 29, 1984.

${ }^{2}$ Research Assistant, Crop Protection Department, Lajas Agricultural Research and Development Center, and Plant Breeder, Horticulture Department, Agricultural Experiment Station, University of Puerto Rico, College of Agricultural Sciences, Mayagüez Campus, Río Piedras, P. R.

${ }^{3}$ Conjunto Tecnológico para la Producción de Cítricas. 1977, Esta. Exp. Agric. Univ. P. R. Publ. 113 
the trees were 11 to 14 years old, data on fruit production was collected from each tree. Fruits were harvested yearly from each clonal variety and a sample was analyzed for $\mathrm{pH}$, ascorbic acid, citric acid and juice content. A 10-fruit sample of each clonal variety was picked to determine mean fruit weight, fruit size and number of seeds per fruit. Juice was extracted with a hand squeezer, weighed, juice percentages, and Brix values were determined. The data obtained was not analyzed statistically because of the lack of randomization of the planting and unequal number of trees per clonal variety.

\section{RESULTS AND DISCUSSION}

Table 1 presents data on average fruit production, fruit size, number of seeds per fruit, mean weight of fruits and juice and percentage of juice yield of the 21 clonal varieties evaluated during the 3 years (1977-78 to 1979-80). The Orlando Tangelo N produced the highest number of fruits per tree with an average of 771 fruits per tree. Temple 15-4-278, Pineapple $\mathrm{N}$, Temple 15-4275 and Valencia 10-12-7 were the best yielders among the sweet oranges with 480, 436, 334 and 331 fruits per tree, respectively. Data published by Troche-Ducot and González-Villafañe ${ }^{4}$ shows that the average production in Puerto Rico in commercial orchards is 124 fruits per tree. In 1969 Espinet $^{5}$ reported that the average production for Valencia and Washington Navel in Puerto Rico was about 86 fruits per tree, and that the average production in Florida for Valencia was 320 fruits. In our evaluations most of the sweet oranges produced very good yields, higher than those reported previously.

Seed content was variable and distinctive of each clonal variety. Pineapple, Temple and Orlando Tangelo were the most seedy with 18, 13 and 13 seeds per fruit, respectively. Among the Valencia oranges, the number of seeds ranged from 3 to 7 , which is quite low if compared with Pineapple. Lue Gin Gong and most of the Valencia clones had a higher juice content than other clones. Table 2 presents the juice analysis of the 21. clonal varieties. According to Moscoso and Capó ${ }^{6}$, Brix, $\mathrm{pH}$, ascorbic acid and citric acid content are important juice characters useful for identification of citrus fruits. In the orange group, Brix varies from 14.5 in Pineapple 1-9-31 to 11.0 in Lue Gin Gong 9-14-23. Tahiti lime 31-1-8 had the lowest Brix, 9.00. Ascorbic acid $(\mathrm{mg} / 100 \mathrm{ml})$ content was higher

\footnotetext{
${ }^{4}$ Troche-Ducot, J. L. y E. González-Villafañe, 1982. Costos e Ingresos en la Producción Comercial de Chinas Valencia y Nebo en Puerto Rico, Esta. Exp. Agric. Univ. P. R. Publ. 145.

${ }^{5}$ Espinet-Colón, G., 1969. Producción y Estructura del Mercadeo de Cítricas en Puerto Rico, Esta. Exp. Agric. Univ. P. R. Bol. 215.

${ }^{6}$ Moscoso, C. G. and B. G. Capó, 1973. Characteristic (Descriminant Function) indices of chironja, orange and grapefruit, J. Agr. Univ. P. R. 57 (1):
} 
TABLE 1.-Number of fruits per tree, fruit size, number of seeds per fruit, average fruit and juice weight and percentage of juice yields per fruit of 21 citrus clonal varieties. Mean of 3 years $(1977-80)$

\begin{tabular}{|c|c|c|c|c|c|c|c|c|}
\hline \multirow[t]{2}{*}{ Clonal variety } & & \multirow{2}{*}{$\begin{array}{c}\text { Number } \\
\text { of } \\
\text { fruits/tree }\end{array}$} & \multicolumn{2}{|c|}{ Fruit size } & \multirow[t]{2}{*}{$\begin{array}{c}\text { Number } \\
\text { of } \\
\text { seeds/fruit }\end{array}$} & \multicolumn{2}{|c|}{$\begin{array}{c}\text { Mean } \\
\text { weight }\end{array}$} & \multirow[t]{2}{*}{ Juice yield } \\
\hline & & & Diam & Length & & Fruit & Juice & \\
\hline & & \multicolumn{4}{|c|}{$\mathrm{cm}$} & \multicolumn{2}{|c|}{$g$} & $\%$ \\
\hline Marsh Seedless & $(G)^{1}$ & 170 & 9.7 & 8.6 & 6 & 450 & 182 & 40.4 \\
\hline Red Blush & $(\mathrm{G})$ & 340 & 9.3 & 8.9 & 6 & 387 & 159 & 46.7 \\
\hline Parson Brown & $(0)$ & 120 & 6.6 & 6.6 & 8 & 148 & 64 & 43.2 \\
\hline \multicolumn{9}{|l|}{ Washington } \\
\hline Navel N & $(0)$ & 222 & 8.2 & 7.9 & 3 & 284 & 113 & 39.8 \\
\hline Pineapple $\mathrm{N}$ & $(0)$ & 436 & 7.3 & 7.0 & 18 & 185 & 79 & 43.8 \\
\hline Pineapple 1-9-31 & $(0)$ & 134 & 6.8 & 6.8 & 18 & 116 & 69 & 39.6 \\
\hline \multicolumn{9}{|l|}{ Lue Gin Gong } \\
\hline $9-14-16$ & $(0)$ & 170 & 7.3 & 7,0 & 2 & 212 & 120 & 56.6 \\
\hline \multicolumn{9}{|l|}{ Lue Gin Gong } \\
\hline $9-14-23$ & $(0)$ & 178 & 7.4 & 7.2 & 5 & 211 & 117 & 55.4 \\
\hline \multicolumn{9}{|l|}{ Temple } \\
\hline $15-4-275$ & $(0)$ & $3: 31$ & 7.1 & 6.7 & 13 & 180 & 90 & 49.9 \\
\hline \multicolumn{9}{|l|}{ Temple } \\
\hline $15-4-278$ & $(0)$ & 480 & 7.0 & 6.2 & 13 & 181 & 90 & 49.7 \\
\hline \multicolumn{9}{|l|}{ Valencia } \\
\hline $10-12-7$ & (O) & 344 & 7.0 & 6.8 & 7 & 210 & 103 & 49.0 \\
\hline \multicolumn{9}{|l|}{ Valencia } \\
\hline $51-1-9 X$ & (O) & 127 & 6.7 & 6.5 & 7 & 158 & 86 & 54.4 \\
\hline Valencia N & (O) & 188 & 7.8 & 7.5 & 6 & 235 & 123 & 52.2 \\
\hline \multicolumn{9}{|l|}{ Valencia } \\
\hline $9-14-18$ & (O) & 125 & 7.2 & 7.0 & 4 & 213 & 107 & 50.2 \\
\hline \multicolumn{9}{|l|}{ Valencia } \\
\hline $16-14-22 X$ & $(0)$ & 130 & 7.8 & 7.5 & 6 & 250 & 140 & 56.0 \\
\hline \multicolumn{9}{|l|}{ Valencia } \\
\hline $9-27-15$ & (O) & 118 & 7.1 & 6.7 & 5 & 200 & 106 & 53.0 \\
\hline \multicolumn{9}{|l|}{ Valencia } \\
\hline 26-1-1XE & $(\mathrm{O})$ & 121 & 7.5 & 7.4 & 3 & 240 & 131 & 54.6 \\
\hline \multicolumn{9}{|l|}{ Valencia } \\
\hline $47-8-35 X$ & $(0)$ & 141 & 7.3 & 6.9 & 7 & 205 & 111 & 54.1 \\
\hline \multicolumn{9}{|l|}{ Orlando } \\
\hline Tangelo N & & 771 & 7.8 & 6.4 & 13 & 246 & 109 & 44.3 \\
\hline Dancy 9-14-1 & $(\mathrm{Tn})$ & 598 & 6.7 & 5.2 & 8 & 140 & 47 & 33.6 \\
\hline Tahiti $31-1-8$ & (L) & 306 & 5.3 & 6.4 & 1 & 109 & 61 & 56.0 \\
\hline
\end{tabular}

${ }^{1} \mathrm{G}=$ grapefruit; $\mathrm{O}=$ orange; $\mathrm{Tn}=$ tangerine; $\mathrm{L}=$ lime; $\mathrm{N}=$ nucellar.

in Pineapple 1-9-31 and Pineapple $\mathrm{N}$ and very low in Tahiti lime 31-18. The highest content of citric acid was found in the Tahiti lime 31-1-8, whereas the lowest content was obtained in the Parson Brown cultivar.

Red Blush was superior to Marsh Seedless in fruit production among the grapefruit varieties. An average yield of 340 fruits per tree was 
obtained from the Red Blush cultivar, whereas 170 fruits per tree were obtained from the Marsh Seedless. Marsh Seedless was higher in citric acid content than Red Blush. In general, the grapefruits were lower in Brix, $\mathrm{pH}$ and ascorbic acid content than the oranges.

Evaluating all the citrus fruits as a whole with regard to size and weight these might be classified as follows: 1) grapefruits-medium, 2) tangelos and sweet oranges - medium small to medium-and 3) tangerines and limes small.

There are some cultivars that seem very promising and should be

TABLE 2.-Brix, pH, ascorbic and citric acid contents in the juice of 21 clonal varieties. Mean of 3 years (1978-80)

\begin{tabular}{lrrcr}
\hline \multicolumn{1}{c}{ Clonal variety } & Brix & $\mathrm{pH}$ & Ascorbic acid & Citric acid \\
\hline & & & $\mathrm{mg} / 100 \mathrm{ml}$ & $\mathrm{mg} / 100 \mathrm{ml}$ \\
Marsh Seedless & 9.8 & 3.1 & 37.9 & 1330 \\
Red Blush & 10.8 & 3.4 & 33.8 & 984 \\
Parson Brown & 14.0 & 4.4 & 54.2 & 470 \\
Washington Navel N & 13.1 & 4.1 & 44.8 & 509 \\
Pineapple N & 13.6 & 3.7 & 71.7 & 926 \\
Pineapple 1-9-31 & 14.5 & 4.1 & 76.5 & 950 \\
Lue Gin Gong 9-14-16 & 11.5 & 3.5 & 49.1 & 1076 \\
Lue Gin Gong 9-14-23 & 11.0 & 3.5 & 48.0 & 1031 \\
Temple 15-4-275 & 13.1 & 3.3 & 63.4 & 1229 \\
Temple 15-4-278 & 13.1 & 3.4 & 62.5 & 1155 \\
Valencia 10-12-7 & 11.6 & 3.7 & 52.7 & 1175 \\
Valencia 51-1-9X & 12.1 & 3.6 & 52.7 & 1114 \\
Valencia N & 11.6 & 3.6 & 49.9 & 913 \\
Valencia 9-14-18 & 12.6 & 3.4 & 46.8 & 927 \\
Valencia 16-14-22X & 11.8 & 3.4 & 47.6 & 1149 \\
Valencia 9-27-15 & 12.1 & 3.4 & 48.1 & 1015 \\
Valencia 26-1-1XE & 11.3 & 3.3 & 45.5 & 1035 \\
Valencia 47-8-35X & 12.1 & 3.3 & 49.5 & 1181 \\
Orlando Tangelo N & 13.0 & 3.9 & 28.3 & 779 \\
Dancy 9-14-1 & 11.6 & 3.3 & 34.0 & 1001 \\
Tahiti 31-1-8 & 9.0 & 3.2 & 21.0 & 6868 \\
\hline
\end{tabular}

recommended for further study and for planting on a large scale. These are sweet orange-Pineapple N, Valencia 10-12-7, Temple 15-4-278, and Tangelo-Orlando N.

\section{RESUMEN}

Se evaluó la producción y las caracterésticas de la fruta de 21 variedades clonales de cítricas (chinas ${ }^{7}$, toronjas, mandarinas, tangelos y limas). La producción media en 1977-80 para clones de Pineapple, Temple y la

${ }^{7}$ Naranja dulce. 
mayoría de los de Valencia fue mucho más elevada que la informada de huertos comerciales en Puerto Rico. Los clones de Pineapple, Temple y Orlando Tangelo tuvieron el mayor número de semillas por fruta con 18 , 13 y 13 , respectivamente. El número de semillas por fruta fue aceptable en la mayor parte de las variedades clonales evaluadas. Los clones de Lue Gin Gong y la mayor parte de los Valencia produjeron el mayor porcentaje de jugo por fruta. 